\title{
Fracture of Femur Related to Birth
}

National Cancer Institute

\section{Source}

National Cancer Institute. Fracture of Femur Related to Birth. NCI Thesaurus. Code

C116829.

A broken femur sustained during the birthing process. 